\title{
Alzheimer's and the Dementia of God
}

\author{
Peter Kevern \\ The Queen's Foundation for Ecumenical Theological Education, \\ Birmingham, $U K$
}

\begin{abstract}
Recent developments in the theory and practice of care for persons with dementia have reopened questions, traditionally explored by theologians, to do with the nature of personal identity and its dialectical relationship to social recognition. This new perspective on classical theological questions serves as a potential theological resource in contemporary western society, where God appears to have withdrawn from the prevailing public discourses. In this article, I explore the analogical potential of imagery of a 'dementing God', as a way to describe the contemporary experience of western Christians, to develop appropriate responses to the current climate in public theology and to continue to talk of God in public, while respecting Bonhoeffer's desire to celebrate a secular world in which humanity may 'come of age'.
\end{abstract}

\section{Keywords}

Alzheimer's disease, dementia, Bonhoeffer

\section{Introduction}

You show me two faces, That of a flower opening And of a fist contracting Like the gripping of ice.

You speak to me with two Voices, one thundering On the ear's drum, the other One mistakeable for silence. 
Father, I said, domesticating

An enigma; and as though

To humour me you came.

But there are precipices

Within you. Mild and dire,

Now and absent, like us but

Wholly other-which side

Of you am I to believe?

Like much of his poetry, this piece by R. S. Thomas speaks of his encounter with God, and specifically of its strangeness and intractability. My first encounter with the poem was in a book on dementia since, as Goldsmith (the author of the book) points out, the dialogue with the dementing person can be 'uncannily described' in this way. ${ }^{1}$

Whether we like it or not, we are accustomed to thinking of God as a venerable old man. Yet to confuse that image with one of a dementing old man, perhaps burbling or screaming, perhaps dribbling and incontinent, is shocking and maybe even blasphemous. We have to ask, then, what gives Thomas' poem about God resonance in relation to the experience of dementia, and how that translocation of images in turn informs our theology.

By way of an answer to the question of resonance, we may note that observing the progress of dementia ${ }^{2}$ is both a distressing and increasingly familiar part of our experience, as dementia becomes increasingly common across the western world. For many, the experience is one of a soul-crushing, painful struggle against the departure of a loved one, in which abstract philosophical and theological questions crop up in the most practical ways imaginable. ${ }^{3}$ Dementia forces us to ask what constitutes a person before God, and how it is that we continue to recognize them when the accustomed markers of personality are disappearing. Conversely, some carers might speak almost

1) R. S. Thomas, Counterpoint (Newcastle upon Tyne: Bloodaxe Books, 1990), as cited by Malcolm Goldsmith, Hearing the Voice of People with Dementia: Opportunities and Obstacles (London: Jessica Kingsley Publishers, 1996), p. 6.

2) I am using this term instead of the now-common 'Alzheimer's disease', for reasons I will discuss in the text, although no terminology is ideal for these purposes. See Richard Cheston and Michael Bender, Understanding Dementia: The Man With the Worried Eyes (London: Jessica Kingsley Publishers, 1999).

3) For example, Donald Keck refers to Alzheimer's as 'The Theological Disease'; David Keck, Forgetting Whose We Are: Alzheimer's Disease and the Love of God (Nashville: Abingdon Press, 1996), p. 38. 
mystically of their relationship with the dementing person, an ineffable 'I-Thou' quality that persists even when the conventional features of relationship have long gone.

The theological issue is less straightforwardly answered. It seems to me that Thomas is not by any means the only Christian in the last century or so to find that the God they thought they knew has become elusive and meaningless; their words seem to have become hollowed out from within, God's 'personhood' and 'identity' seem to have leaked away, becoming shadowy and conventional. 'Father God' is becoming opaque to us and is in the process of dissolution; not dying, not fleeing, but dissolving, becoming incommunicative and incommunicable. Like a dementing old man, God is receding from us, and we are perplexed at how to respond. Our God is a dementing God.

It is worth remembering that this sense of God's withdrawal is a distinctively western (perhaps narrowly European) phenomenon, and that secularization has not taken place on the global scale that Max Weber's successors have at times predicted. ${ }^{4}$ Furthermore, in the western context there are many people for whom this withdrawal does not present any great challenges; indeed, for some people, such as Richard Dawkins, ${ }^{5}$ the disappearance of God is an accomplished and unremarkable fact, while theology is a curious survival of a bygone age. For others, such as Stanley Hauerwas, ${ }^{6}$ their fideist or emotivist commitments effectively insulate them from the secular challenge, since they believe in or 'feel' God without reference to the wider world of experience and reason in which the question of plausibility might arise. However, there are some of us for whom secularism still presents a challenge, if not to God's existence, then to God's meaning. We believe in God, for what it's worth, but we have difficulty recognizing God, finding any 'point' to God. In a world where human personhood itself seems no more a 'given' than the personhood of God, we sense a common cause with God; a sense that if we let God go so easily, humanity will start to slip through our fingers in the same way. Frankly, we miss God; thus, even dementing, we are not yet ready to let God go.

I am aware that by using the phrase 'dementing God', I may be setting some false trails. To clarify, I am not seeking to diminish or humiliate God;

\footnotetext{
4) See William H. Swatos, Jr and Daniel V. A. Olson, eds, The Secularization Debate (Lanham: Rowman and Littlefield, 2000).

5) Richard Dawkins, The God Delusion (London: Bantam Press, 2006).

6) Stanley Hauerwas, The Hauerwas Reader, ed. John Berkman and Michael Cartwright (Durham, NC: Duke University Press, 2001).
} 
that is, this is not so much about what God is in Godself as about our perception of God in the public sphere. There is no question of God suffering some kind of physical-neurological impairment and of 'losing his mind'. Instead, I want to focus on the changes that dementia effects in a person's relationships, their roles and place in wider society, and the connection of this to a 'malignant social psychology' that both reflects and contributes to their deterioration. ${ }^{7}$ It is in this latter sense that I intend to talk of God as dementing: of becoming increasingly unrecognizable to us and marginal to our social concerns, to the point of becoming an inconvenience and an embarrassment.

Secondly, I am not proposing a model of 'dementing God' along the lines of Eiesland's 'Disabled God' or Isherwood's 'Fat Jesus, ${ }^{8}$ as an example of the way our restricted imagery for God excludes certain persons. I am instead seeking to drive the analogical process in the opposite direction, beginning from the assumption that our restricted imagery for persons excludes God, and that to enrich that imagery is to create new opportunities for naming, recognizing and celebrating the presence of God in the contemporary world. As times and contexts change, so the 'person' of God must be rendered anew in our discourse: as a way of negotiating life, as a duty to God, and finally because we cannot stop theologizing. We need to reflect on the world in which we find ourselves, and from that build a conception of God that responds to that world.

The proposal I will explore and develop is that, for those of us who are western theologians seeking to make sense of God in a predominantly secular context, there is much to be learnt from those whose profession is the understanding and care of people with dementia. The day-to-day experience of being in the presence of persons who do not bear the conventional marks of personhood; the daily challenge of interpreting words and gestures that have ceased to carry conventional content; the forced critiquing and challenging of notions of human worth and even of human life; these are all related analogously to the day to day challenge of living with a 'dementing God'. The majority of this article will therefore be an attempt to 'theologize' some

\footnotetext{
7) See Tom Kitwood, Dementia Reconsidered (Buckingham: Oxford University Press, 1997) and Clive Baldwin and Andrea Capstick, eds, Tom Kitwood on Dementia: A Reader and Critical Commentary (Buckingham: Oxford University Press, 2007).

8) Nancy L. Eiesland, Disabled God: Towards a Liberatory Theology of Disability (Nashville: Abingdon, 1994) and Lisa Isherwood, The Fat Jesus: Feminist Explorations in Boundaries and Transgressions (London: Darton, Longman and Todd, 2007).
} 
insights from the world of dementia care. Although at times it will be necessary to make distinctions, I will treat those writing in the field of dementia care as if they were writing theologically, and so avoid a rather cumbersome separation between description and application of a writer's thought.

\section{Dementia and the Medicalization of a Social Problem (or Vice Versa)}

As western society 'takes leave of God', ' it is convenient to blame the patient, or at least 'his' apologists on earth. ${ }^{10}$ The notion of God has become sick, otiose, irrelevant and disruptive to our independent, driven and demanding lives. We cannot be blamed for jettisoning the concept in such an apparently unfeeling manner, because God has demented.

To follow up the analogy that I am developing, it is instructive to reflect on a parallel tendency in responses to those who are dementing: the tendency to treat dementia in medicalized and individualized ways that, in effect, cast the whole situation as due to changes in the 'patient'. The 'default position' in dementia care is to treat it not as a social phenomenon but as a medical one; as the result of changes in an individual's brain, over which society has no control and in response to which it can only offer medical intervention. Furthermore, dementia is treated as a problem within the individual; an 'internal' matter that is supposedly independent of the actions and reactions of those around the affected person. This is well demonstrated by the increasing prevalence of the term 'Alzheimer's Disease' for any form of progressive mental impairment in a hitherto 'normal' person. A disease is nobody's fault, and external to both 'patient' and their circumstances; thus, it implies a contrast with health and normality, and so creates an expectation of the patient as passive victim. ${ }^{11}$

There is however an alternative paradigm, which understands the term 'dementia' as at least partly to do with the way a person is perceived, understood and located within a social and historical setting. Hence, while personal change is inevitable, it is 'malignant social psychology' that de-positions the dementing person and so pathologizes them. In other words, while the individual is undoubtedly losing some cognitive capacity, the consequences of

\footnotetext{
9) Don Cupitt, Taking Leave of God (London: SCM Press, 2001).

10) I am using the masculine pronoun for God to reinforce the analogy between traditional imagery for God and that of a 'dementing old man'.

11) See Cheston and Bender, Understanding Dementia.
} 
this loss are intimately connected with their social and historical circumstances. ${ }^{12}$ Thus, in Kitwood's 'dialectical model' of dementia, there is a vicious spiral in which changes in the individual lead to their increasing marginalization, disempowerment and isolation, and these are conditions that in turn accelerate and contribute to a further round of decline. ${ }^{13}$ According to Sabat, 'malignant social positioning' detracts from the self-appreciation of the dementing subject and so contributes to the situation it aims to help; that is, language of loss actually takes away from both carers and subject. ${ }^{14}$ The problem is not simply a malfunction in a person's brain, but a malfunction in the philosophical and theological underpinnings of society's understandings of 'person'. 15

On this model, what 'dements' is not so much an individual as an entire socially held world of meanings; whereby meaning becomes impaired, forgetful and erratic in a shared malignant process. From this perspective, we may begin to see what it might mean to talk of the 'dementia' of God: a whole set of relationships, shared meanings and assumptions breaks down, with the result that God appears to have become opaque to us, to have withdrawn from or become unresponsive to us, to have become forgetful of us.

As in the care of a dementing person, our response to this 'dementing God' should be a self-reflective one. Rather than focussing exclusively on a change in the individual (over which we have little control), we should pay close attention to our social reactions (over which we should have much more control). God is unlikely to have changed, but the only God we can know is the one who appears as a participant in our socially constructed world, in which the 'communion of saints' constructs an image of God as it constructs the church. If God seems to be withdrawing from us, it is because our deep assumptions of what God's presence with us looks like are being challenged.

12) Kitwood, Dementia Reconsidered and Tom Kitwood, 'Person and Process in Dementia', in Baldwin and Capstick, eds, Tom Kitwood on Dementia, p. 67.

13) Baldwin and Capstick, eds, Tom Kitwood on Dementia, p. 12.

14) Steven R. Sabat, 'Mind, Meaning and Personhood in Dementia: The Effects of Positioning', in Julian C. Hughes, Stephen J. Louw and Steven R. Sabat, eds, Dementia: Mind, Meaning and the Person (Oxford: Oxford University Press, 2006), pp. 287-302.

15) 'one's basic view of aging, and thus of people who are elderly (and perhaps especially cognitively impaired) is not a scientific factual matter at all, though obviously certain facts are relevant. The question of attitudes towards aging — what it means to grow old and how one should relate to people who are old-is a theological/philosophical question, that is, a question of value and ultimately of faith'; Stephen Sapp, 'Memory: The Community Looks Backward', in Donald McKim, ed., God Never Forgets: Faith, Hope and Alzheimer's Disease (Louisville: Westminster John Knox, 1997), pp. 38-54 at p. 54. 
To understand God's 'dementing' we must examine the contemporary challenge to previous assumptions about God.

\section{Diagnosing the Dementia of God}

As we have noted, the care of a dementing person challenges in a particularly sharp way our understanding of what it is to be a person. We do not, by and large, respond to the suspicion that somebody's brain is faulty; rather, we respond to the tragic sense that somebody's personhood is ebbing away, which may be expressed in statements such as 'she is no longer the person she used to be' and 'he's been dead for ages-he just hasn't stopped breathing yet'. ${ }^{16}$ Our working understanding of 'personhood' is typically inductive rather than analytic; in other words, we infer that there is a person 'in there' because of the way they behave 'out here', in the social world, as is easily demonstrated by an analysis of the stories of and about dementing people. ${ }^{17}$ The key issues are behavioural rather than metaphysical, and are interrelated in complex ways.

First, there is narrative integrity. As memory declines, so does the person's ability to give an account of how they got here and what carries meaning in their life. If, for example, a woman has devoted her entire life to the nurture and care of her children, then at the point where she no longer recognizes them the inference may be that she is herself no longer recognizable as the person she once was. Secondly, there is intentional activity. A disturbance in the person's behaviour is often the first symptom of dementia to the casual observer; such that their activity may appear to be inexplicable and spasmodic, with no clear plan or outcome. As such, the process by which we infer the presence of an intentional agent is interrupted. Thirdly, there is social interaction. It is clear that people with dementia often become less able to interact with the social world at a pace and in a way comprehensible to those around them, thus becoming both socially and politically invisible. Although

\footnotetext{
16) In one case of 'mercy killing' of a demented person by their carer, the judge showed leniency, stating: '[you] tried to care for a woman, who ceased to be the woman you married'; BBC News (2003), reported by Carmelo Aquilina and Julian C. Hughes, 'The Return of the Living Dead: Agency Lost and Found?', in Hughes, Louw and Sabat, eds, Dementia, pp. 143-63 at p. 144.

17) See, for example, Robert Davis, My Journey into Alzheimer's Disease (Oxford: Tyndale House 1986) and Elizabeth Forsythe, Alzheimer's Disease: The Long Bereavement (London: Faber \& Faber, 1990).
} 
often overlooked, this is the most obvious of the senses in which one may be said to be a 'person'. The term is a linguistic one, and as such follows a set of shared rules and meanings. Hence, one is a person to the extent to which one is recognized as such, is noticed, valued and heard within the world. A 'person' who has no weight in the social and political world is hardly worth the name. Thus, as Kitwood notes, depersonalization takes place by a combination of internal and external factors. ${ }^{18}$

It is perhaps only when these key characteristics are obscured that our dependence on them for the inference of a personal 'identity' becomes clear; that is, without them, the individual seems to melt away to nothing. We have to consider, therefore, the extent to which the 'person' still is in existence when the characteristics associated with them are all in flux. ${ }^{19}$

If these perceived changes provide the reasons why we may conclude that somebody has ceased to be an identifiable person, then we may expect to find analogous changes in the recent history of western religion that generate the sense that God is 'dementing'. First, at the level of narrative integrity, for many it is no longer plausible to claim that the Scriptures or the traditions of the church tell a single unified story of God's dealings with the created order, and one which univocally locates him within a narrative that includes us. Secondly, God is not generally understood as an intentional agent in the details of history, intervening to accomplish particular purposes in a way that suspends the natural order of things. Finally, and perhaps because of the other changes, God has simply dropped out of public discourse, so that theologians at best struggle to generate a shared conversation about God, while Rawlsians advocate relegating the term 'God' to the restricted language games of bounded faith-communities. ${ }^{20}$ God has at best a phantom presence in our public discourse.

However, in the light of the discussion above, we should note that we actively collaborate in the creation of each other's 'identities', providing the prompts for memory, the arena for action and the social status that contributes to them. Analogously, God's apparent withdrawal says something about

\footnotetext{
18) Kitwood, Dementia Reconsidered, p. 8.

19) See Keck, Forgetting Whose We Are, p. 122: 'the phenomena of Alzheimer's render the selfconscious subject as the ground for theological and religious life highly suspect. Because the real experiences of patients are so contrary to the experiences of consciousness, it is simply unclear how... theologies can address adequately the theological dimensions of dementia without compromising... assumptions'.

20) John Rawls, Political Liberalism (New York and Chichester: Columbia University Press, 1993).
} 
our inability to 'make space' for God on the one hand, and our inability to perceive God's presence on the other. If we share responsibility for each other's identity, it follows that there are things we can do to create a more responsive environment and attend more closely to God. There are also things that we may have to learn, or relearn, before the face of a God who is no longer communicating with us in the accustomed manner. Thus, we are all implicated in the disappearance of God by virtue of the fact that we supply the social context: the perceived withdrawal of God is symptomatic of deterioration in a whole set of relationships. The literature on care for those with dementia proves to be rich in insights that can be used to address this deterioration.

\section{Caring for God-Reconstructions}

When we turn to consider the ways in which the personhood of the 'dementing God' may be supported and even reconstructed in the speech and activity of the Christian community, three overlapping themes are identifiable in the literature on dementia care that merit consideration in a theological framework.

\section{Rementing-Restoring the Missing Links}

One of the more controversial theories in dementia care suggests that, because neurological impairment is only one of a number of factors in dementia and because memory is socially held in a collaborative process, some degree of reversal, of 'rementia' is possible. ${ }^{21}$ This means that when an individual's ability to remember starts to falter, others may 'hold' that memory for them by surrounding them with familiar elements and orientating them by familiar landmarks in their own story. To the extent that personhood itself depends upon memory and a sense of narrative continuity, we may even say that they hold and support that individual's integrity as a person by, for example, reminding them of recent events and decisions and locating these within a narrative framework. ${ }^{22}$

An essential element of Christian devotion is a 'rementing', or more familiarly 'anamnesis', reconstituting God's identity and presence by recounting

\footnotetext{
21) See Baldwin and Capstick, eds, Tom Kitwood on Dementia, pp. 16-18.

22) See Julian C. Hughes, Stephen J. Louw and Steven R. Sabat, 'Seeing Whole', in Hughes, Louw and Sabat, eds, Dementia, pp. 1-39 at p. 16.
} 
God's story. Although the focus of this process is typically seen as the remembering community (including those who themselves have dementia), ${ }^{23} \mathrm{I}$ would argue that it is of significance for the identity of a 'dementing God'. God inhabits the story as it is being told; God's identity becomes rendered in the present through the retelling of the story of the past. ${ }^{24}$

Like carers surrounding the dementing person with familiar emblems and landmarks, we surround God with memories drawn from shared tradition and personal testimony. The identity of the 'people of God' is dialectically linked to the regular rementing of God; God and God's people come into being together and take their identity from each other. As with the presence of a dementing relative, in the religious community we scatter around reminders of our relationship, so that in re-membering God we may ourselves be remembered. ${ }^{25}$

\section{Benign Social Psychology?}

As we have noted, when God drops out of public discourse, God's very identity is in question. According to Wittgenstein, words are necessarily signifiers of shared meaning, and to have a 'private' meaning for a word is an oxymoron. ${ }^{26}$ The closed circles of discourse described, for example, by Lindbeck's 'cultural-linguistic theology' or Fish's communities of interpretation will, therefore, only take us so far. ${ }^{27}$ Lindbeck and Fish preserve a discursive niche for God, but at the price of insulating the term from the wider, overlapping discourses in which we all take part. It is as if the dementing God is allowed to potter around in the care home, but must on no account be allowed out to

\footnotetext{
23) Stephen Sapp, 'Memory: The Community Looks Backward', in McKim, ed., God Never Forgets, pp. 38-54 at p. 52.

24) See, for example, Thomas W. Mann, The Book of the Torah: The Narrative Integrity of the Pentateuch (Louisville: Westminster John Knox Press, 1988), p. 150.

25) The relational ontology developed by Zizioulas raises the intriguing possibility that such remembering may have ontological weight such that God's being may be co-constituted in the worship of the community, but Zizioulas would have been horrified by this notion. Cf. John Zizioulas, Being as Communion (New York: St Vladimir's Seminary Press, 1985) and John Zizioulas, Communion \& Otherness (London: T\&T Clark, 2006).

26) Ludwig Wittgenstein, Philosophical Investigations, trans. G. E. M. Anscombe, P. M. S. Hacker and Joachim Schulte, 4th edn (Wiley-Blackwell, [1953] 2009), pp. 98-99.

27) George A. Lindbeck, The Nature of Doctrine: Religion and Theology in a Postliberal Age (Philadelphia: Westminster, 1984); Stanley Fish, Is There a Text in this Classroom? The Authority of Interpretive Communities (Cambridge, MA: Harvard University Press, 1980).
} 
breathe the fresh air. We need to find meanings in the wider world of discourse, if our God is to have a home there.

There is a range of emergent resources in theology for talk of a God in a wider discourse. The most promising candidate may be the Girardian claim that the Christ-story has had a thoroughgoing subversive effect on 'Christian' societies, by shifting their dominant perspective from that of the powerful to that of the victim. ${ }^{28}$ We might also consider the theme of a God who is in history, and so interwoven with discourse, such as Moltmann's or that of process theology. ${ }^{29}$ Perhaps the image of a dementing God is an example of a vulnerable and participatory God.

\section{Reflection: On 'Constructing' What Is Not There}

The constructivist approaches above recognize both the truth of the other and our responsibility to maintain our side of the relationship, which is intensified when the other is incapable of maintaining their side of it. Such approaches resist the notion that God has 'gone' or become a 'husk' of an idea, and, in Post's terminology, provide 'prostheses' for the images of God that have been lost to us. ${ }^{30}$ Thus, these approaches emphasize that, as 'God' ceases to be an assumed social fact, more of the burden of construction falls to us: we have to grow up, and take responsibility for defining God in the way that 'God' used to take responsibility for defining us. To put this in the idiom of dementia care, then, we are to take responsibility for 'Active, Collaborative Authorship of the Self-narrative'31 on behalf of God.

There are some limitations and dangers inherent in arrogating to ourselves the task of defining God. The alienation of a person's 'identity' from her or himself to the community is potentially oppressive in that it suggests that we are no more than the social powers make us, ${ }^{32}$ and to avoid this trap we must assume an independent existence for God, whether we recognize it or not. ${ }^{33}$ This is the other, 'essentialist' pole of the dialectic; that is, there is indeed a

\footnotetext{
28) René Girard, I See Satan Fall Like Lightning (Leominster: Gracewing, 2001).

29) Jürgen Moltmann, The Crucified God (London: SCM, 1974); Charles Hartshorne, Omnipotence and Other Theological Mistakes (Albany: State University of New York, 1984), pp. 20-26.

30) Stephen G. Post, 'Respectare: Moral Respect For the Lives of the Deeply Forgetful', in Hughes, Louw and Sabat, eds, Dementia, pp. 223-34 at p. 229.

31) Hughes, Louw and Sabat, eds, Dementia, p. 15.

32) Tim Thornton, 'The Discursive Turn, Social Constructionism, and Dementia', in Hughes, Louw and Sabat, eds, Dementia, pp. 125-41.

33) 'Personhood... can be bestowed, it can... be equally easily withheld'; Baldwin and Capstick, eds, Tom Kitwood on Dementia, p. 180.
} 
God who is in communication with us, albeit in ways that we have difficulty recognizing and interpreting. With a renewed attention to God's social being, there must be renewed attention to God's communicative being.

\section{Beyond Constructivist Responses}

People with dementia appear to have ceased to communicate, and constructivism is one response to that fact. A complementary response is to treat the breakdown in communication as a social problem suggesting that there may be an attempt to communicate, which we are unable to recognize. There is an increasing body of literature that proposes the complementary approach, and seeks signs among people with dementia of a continuing, though changed, self-expression. ${ }^{34}$ For example, silence or a refusal to cooperate can be read as responses to a situation, rather than as 'difficult episodes' or behavioural disturbance. ${ }^{35}$ By analogy, we may ask in relation to the dementing God what positive consequences arise from God's apparent withdrawal and silence, from which we may infer God's continued involvement with our future.

\section{Critique of Infantilism}

The question of God's apparent disappearance as an intentional agent in the physical world has been extensively worked over throughout the twentieth century by Christians, sceptics and atheists alike. In conceding to the modernist critiques, scholars may argue that to seek a God who occasionally intervenes in an otherwise ordered universe is to set out on the wrong quest, and so to overlook the obvious explanation that the relationship of God to the world is not one of an isolated intention that issues in a discrete action, instead it is one of a constant creative and participative presence, which may be discernible by us in different ways and to different degrees. ${ }^{36}$

One of the most influential reworkings of this theme was in Bonhoeffer's famous letter of 16 July 1944, in which he criticizes the infantilizing effect of religion, stating: 'Man's religiosity makes him look in his distress to the power of God in the world: God is the deus ex machina', and Bonhoeffer contrasts

34) See Lisa Snyder, 'Personhood and Interpersonal Communication in Dementia', in Hughes, Louw and Sabat, eds, Dementia, pp. 259-76.

35) Aquilina and Hughes, 'The Return of the Living Dead', in Hughes, Louw and Sabat, eds, Dementia, pp. 143-61.

36) See Owen C. Thomas, ed., God's Activity in the World: The Contemporary Problem (Atlanta: Scholar's Press, 1983). 
this with the need, in a secular world, to live etsi deus non daretur. ${ }^{37}$ His suggestion that God allows himself (sic) to be edged out of a secular world and onto the cross so that humanity may come of age resonates with the idea of a dementing God, whereby God may be withdrawing so that we can 'come of age', grow up and take responsibility both for ourselves and our God.

\section{Rebirth of Institutions}

The current situation of God's 'dementing' need not uniformly be expressed in terms of loss but, by analogy with dementia care, be understood as a reconnection with the unpredictability of God, for our healing and growth. As Shabahangi points out, there are benefits to accepting a person with dementia on their terms, since the 'dreamland' they inhabit invites us to attend again to the way in which we marginalize fantasies and suppress those human attributes that do not contribute to the achievement of our goals. ${ }^{38}$ By insight into the 'otherness' of dementia, there may be the opportunity to recover our creativity, playfulness and sense of timelessness. Shabahangi states: 'This otherness allows for the road less travelled, allows us to live our life in the way important to us, not necessarily in the way prescribed for us' ${ }^{39}$

Such a transformation has been evident in the recent history of dementia care, which has seen the conversion of institutions, from standard measurement techniques and protocols of treatment to the recognition that each person with dementia is dementing in a different way, and at a different rate, so that institutional responses just will not do. ${ }^{40}$ The benefits of this reformation of institutional life have been enjoyed not just by those involved in dementia care but at a number of points where persons and institutions intersect. Imagination and creativity flourish best at the points where habitual solutions and responses become impotent.

Paradoxically, it has been as the western church has had to grapple with the elusiveness and intractability of images of God that its ecclesial and theological imagination has been unleashed. In the face of God's otherness, the

\footnotetext{
37) Dietrich Bonhoeffer, Letters and Papers from Prison, ed. John Bowden, 'Letter to Eberhard Bethge [Tegel] 16 July 1944', (London: SCM Press, [1953] 2001), p. 134.

38) Nader Robert Shabahangi, 'Redefining Dementia: Between the World of Forgetting and Remembering' (December 2005), p. 7, <http://www.pacificinstitute.org/events/nader_dementia.pdf> [accessed 28 January 2010].

39) Ibid., pp. 4-5.

40) Although, sadly, the economic and social realities of dementia care sometimes leave them as the only options.
} 
church has been unable and unwilling to maintain a pattern of lock-step conformity, of the sort that could persist in more certain times. The way of discipleship in the current climate is necessarily one of active theological imagination, in which creativity and flexibility have a high premium and fixed institutional patterns quickly prove inadequate.

\section{Critique of Social Values}

In addition to the reformation of our institutions, attention to those with dementia has called into question the essentially Stoic values of control, thrift, rationality and success. According to Post, it invites us to a more relational understanding of life together that draws on the shared Jewish and Christian value of '[e]qual regard based on cognitive, emotional, rational and symbolic-expressive aspects'. ${ }^{41}$ Perhaps God has not changed, but we have forgotten the communicative values that would enable us to communicate, but in communion with people with dementia, we have the opportunity to find them again.

As Christians know, communication before the face of the other requires a contemplative slowness, a self-giving and willingness to be moved from one's own place of security. Thus, Goldsmith states:

Often, difficulties encountered when communicating can be attributed to the pace of the interaction. Communicating with a person with dementia can be a slow process. We must be prepared to devote an adequate and appropriate amount of time to this task. Very often metaphors may be used, which need to be interpreted. Not having enough time and therefore making little progress is not the same as saying that the person is unable to communicate. Communication may be extremely difficult because, for whatever reason, we are not able to devote an adequate amount of time to that specific task. ${ }^{42}$

If 'God' were to replace 'person with dementia' in the passage above, it might easily have been taken from any manual on prayer in the last hundred years. A 'dementing God' is one who shows us the importance of time, of engagement and attachment. What has been lost is not so much the 'presence' of God, as our communicative familiarity with it, in a world where our imaginative and communicative landscape is changing faster than we are able to follow.

41) Post, 'Respectare', in Hughes, Louw and Sabat, eds, Dementia, p. 233.

42) Goldsmith, Hearing the Voice of People with Dementia, p. 76. 
As well as the activism of the 'constructivist' responses, then, the strangeness of our current experience of God recalls us to a contemplative way of relating. The recession of a clear imagery for God, disturbing and disorientating as it may be, has some positive effects in that it opens up a space in which to grow up, to develop new ways of listening and new communicative practices. As a long tradition of mystical theology in both western and western churches testifies, it is at the point at which the images break down that a revelation of God can take place.

\section{Conclusions}

At the beginning of this article, I noted that there is a 'transcendent' element to the care of people with dementia that is evidenced, for example, in the use of Thomas' poetic descriptions of God. The apparent eclipse of someone's identity and personhood in dementia bears comparison with the apparent withdrawal of God in the late modern era. In Keck's words:

We may ask if caring for an Alzheimer's patient is analogous to the worship of God. In both cases, according to some, you do it because it is right, not because you expect any reward, let alone enjoy the comfort of recognition. Both caring for a loved one who no longer knows your name and praying to God in a world full of suffering can be quite painful, even bitter. ${ }^{43}$

Conversely, at this time of the withdrawal of God, we are called to exercise great care, great attention to detail. There is an 'apophatic' element to this project, a recognition that our images of God were always inadequate and that their erosion is an opportunity to grow into the darkness; there is also a 'kataphatic' element, a recognition that it is our responsibility to care for the image of God, to 'rement' God in our current social context.

Hence the rhetorical balance shifts from expecting God to take care of us, to us taking care of God. No longer our provider, God appears now as our dependent. It is no longer God telling us who we are, but us telling God who 'he' is. This can be done with care, with attention, with collaboration and respect; but it is not a task we have a right to refuse.

When this perspective is brought to bear on the imagery of the 'old man in the clouds', which Bonhoeffer feared perpetuated us in a state of infantile dependency, some fertile lines of thought open up. The paternalist imagery

43) Keck, Forgetting Whose We Are, p. 17. 
that Bonhoeffer criticized carried with it the burden of its origins in gerontocratic societies in which the metaphor of great age connoted God's authority, power and self-sufficiency. God has been allied with the sources of secular power, in relation to whom our proper status is that of children; yet, such a God, if 'he' loves us, may well allow 'himself' to be pushed out in order to enable us, in Bonhoeffer's words, to 'come of age'. ${ }^{44}$ He states:

And we cannot be honest unless we recognize that we have to live in the world etsi deus non daretur. And this is just what we do recognize-before God! God himself compels us to recognize it. So our coming of age leads us to a true recognition of our situation before God. God would have us know that we must live as men [or women] who manage our lives without him. The God who is with us is the God who forsakes us (Mark 15.34). The God who lets us live in the world without the working hypothesis of God is the God before whom we stand continually. Before God and with God we live without God. God lets himself be pushed out of the world on to the cross. He is weak and powerless in the world, and that is precisely the way, the only way, in which he is with us and helps us. Matt. 8.17 makes it quite clear that Christ helps us, not by virtue of his omnipotence, but by virtue of his weakness and suffering.

Here is the decisive difference between Christianity and all religions. Man's religiosity makes us look in our distress to the power of God in the world: God is the deus ex machina. The Bible directs man to God's powerlessness and suffering; only the suffering God can help. To that extent we may say that the development towards the world's coming of age outlined above, which has done away with a false conception of God, opens up a way of seeing the God of the Bible, who wins power and space in the world by 'his' weakness. This will probably be the starting-point for our 'worldly interpretation'. ${ }^{45}$

Nevertheless, it would be premature to shelve all images of 'father God' or to replace it with an equally inflexible belief in God's absence. As history shows, such a strategy may have the effect of strengthening its subconscious power and leaving us prey to father-images among our political and religious leaders. Instead, we may seek to renew the image in ways that incorporate God's powerlessness and suffering.

The imagery of the 'dementing God' may subvert and re-present the father-image in a new way. In contemporary society the 'old man' is a figure of fun, connoting powerlessness and dependency. It is allied with those oth-

44) Bonhoeffer, Letters and Papers from Prison, ed. John Bowden, 'Letter to Eberhard Bethge [Tegel] 16 July 1944', p. 134.

45) Ibid. 
ers 'written out' of society, the members who no longer fit, covered by stories told of how the outcast 'prefers it that way'. Theologically, one expression of the theme of a God who 'became weak for us' may be in this very imagery. This is the face of marginalization, and to be countercultural in such a climate is to exalt the figure of the old man, to 're-member' it in as many ways as we are able, to attend to it and allow ourselves to be changed and reformed in the light of it. This construction of God's presence can be responsive both to God and to contemporary society; further, if it challenges the yearning of theologians for eternal truths and all-powerful figures that will insulate them from history that too may be a good thing. 
